\title{
Selected properties of the incipient soils developing on coal mining wastes, Bowen Basin, Australia
}

\author{
AV Spain The University of Western Australia, Australia \\ I Hollingsworth Horizon Environmental Soil Survey \& Evaluation, Australia
}

\begin{abstract}
The limited amounts of available good quality, fully developed soil frequently constrain the success of rehabilitation works. Consequently, the minesoils that develop spontaneously on spoil materials and their transported erosion products in post-mining landscapes must be used as alternative growing media in achieving rehabilitation objectives. The minesoils developing on spoils derived from open cut coal mining in four Bowen Basin mines are defined and selected properties contrasted with those of local, fully-developed soils. These diverse materials reflect the variety of parent materials present and are developing in immature, geomorphologically active landscapes where they are undergoing substantial physical weathering and, in some places, chemical weathering associated with pyrite oxidation. Important physical limitations as growing media include elevated dispersivity, a high tendency towards crust formation and a very limited development of biologically based structure. Minesoil $\mathrm{pH}$, salinity and sodicity range widely and are used to define twelve classes of materials that reflect their potential limitations as growing media and in substrate stability. Extremes are seen as common and major constraints to soil and ecosystem development. Profile development is largely limited to the surface 50 millimetres. For minesoils to develop eventually into soils in approximate equilibrium with contemporary environments and to provide the ecosystem goods and services necessary to support natural patterns of biodiversity, productivity and water quality, their long-term development pathways need to be better understood.
\end{abstract}

\section{Introduction}

Most non-trivial definitions indicate that soil formation is ultimately a consequence of biological activity and that the differences between sediments and fully-developed soils follow from the activities of organisms, the by-products of their metabolism and the structures they create, usually acting over long time periods (see, for example, Johnson and Hole 1994). It follows from such definitions that soil formation processes are strongly linked to the types and intensities of biological activities (Phillips 2009). However, the biological processes that mediate soil development may be greatly constrained by feedback interactions with the chemical environment, inorganic soil components and physical processes.

The undisturbed, fully-developed soil present on a mining lease is a non-renewable resource of considerable value in rehabilitation procedures and may be used to provide a stable and fertile surface cover for underlying wastes and overburdens. However, at the mine scale, good quality natural soil resources are frequently limited and require careful and conservative management to maximise their usefulness. In such environments, it is therefore important to also consider which of the available overburden and interburden materials may most profitably be used as total or partial soil substitutes in rehabilitation procedures. It is particularly important to know what degree of stress may be imposed on the developing vegetation by the limiting properties of potential growing media (Li et al. 2014).

This article examines selected general properties and the development and classification of the incipient soils developing on spoils derived from open-cut coal mining (characterised provisionally as 'minesoils'). Based on data derived from studies conducted at four Bowen Basin mines and representing three major coal measures, it discusses minesoils in the earliest stages of development and presents selected of their physical (field texture, a measure of aggregate dispersivity) and chemical properties ( $\mathrm{pH}$, specific conductance (or electrical 
conductivity, EC) and the sodium adsorption ratio (SAR)), factors important to minesoil development, stability and potentially limiting to plant growth in Bowen Basin coal mine spoils. It briefly examines how these properties can be used to classify spoil materials in ways that are likely to reflect their future development and potentially that of their associated novel ecosystems.

\section{Study location: the Bowen Basin}

The Bowen Basin is among a series of large coal-bearing basins occurring along Australia's east coast (Mutton 2003). It extends from c. $21^{\circ} 33^{\prime}$ to more than $25^{\circ} 21^{\prime} \mathrm{S}$ and c. $147^{\circ} 40^{\prime}$ to $150^{\circ} 20^{\prime} \mathrm{E}$ : it is more than $600 \mathrm{~km}$ long and up to $250 \mathrm{~km}$ at the widest point. The outcrop area is approximately $75,000 \mathrm{~km}^{2}$ (Hutton 2009). The climate is seasonally semi-arid with a summer rainfall maximum. Annual average precipitation lies in the approximate range 550 to $1,000 \mathrm{~mm} \mathrm{y}^{-1}$ and increases from west to east in the Basin.

In 2013-14, the Basin had 41 operating coal mines, with new mines under construction and at least 38 further identified coal deposits (Anonymous 2015a). Mining is predominantly open-cut, with considerable underground mining also being conducted at some sites (Erskine \& Fletcher 2013; Roe et al. 1996).

The data discussed in the present article was derived from sampling conducted during 1993 and 1994 (unpublished reports by Spain et al. 1995b, 1997) at four Bowen Basin mines (Table 1) representing three of the major coal measures in the Bowen Basin (Mutton 2003). The rehabilitated and spoil-pile landscapes studied at Blackwater and Saraji Mines were 13 and 19 years old, respectively; those studied at Gregory Mine were 9 and 6 years, again respectively. The rehabilitated landscapes studied at Oaky Creek Mine had been established for four years at the time of sampling, while the spoil pile landscapes constructed with draglines from the open cut were less than 12 years old.

Table 1 Locations of the four mines and their associated coal measures

\begin{tabular}{ccccc} 
& & \multicolumn{2}{c}{ Mine } & \\
& Blackwater & Gregory & Oaky Creek & Saraji \\
\hline Location & $148^{\circ} 50^{\prime} \mathrm{E}, 23^{\circ} 48^{\prime} \mathrm{S}$ & $148^{\circ} 20^{\prime} \mathrm{E}, 23^{\circ} 10^{\prime} \mathrm{S}$ & $148^{\circ} 31^{\prime} \mathrm{E}, 23^{\circ} 04^{\prime} \mathrm{S}$ & $148^{\circ} 17^{\prime} \mathrm{E}, 22^{\circ} 25^{\prime} \mathrm{S}$ \\
Coal measures & $\begin{array}{c}\text { Rangal coal } \\
\text { measures }\end{array}$ & $\begin{array}{c}\text { German Creek } \\
\text { formation }\end{array}$ & $\begin{array}{c}\text { German Creek } \\
\text { formation }\end{array}$ & $\begin{array}{c}\text { Moranbah coal } \\
\text { measures }\end{array}$ \\
\hline
\end{tabular}

\section{$3 \quad$ Methods}

\subsection{Survey and sampling}

Field texture was assessed on the basis of 355 minesoil samples taken from 98 profiles sampled in both restored and spoil pile environments, mostly at depths up to one metre. A range of landscape locations was sampled in both environments. Some sampling was based on transects across spoil pile and restored landscapes, other sampling was conducted at box cut and low wall locations to encompass potential systematic variation across spoil pile landscapes. Seven local native woodland profiles were also sampled: six vertisols and one alfisol.

For dispersion testing, samples were taken of near-surface aggregates and crust fragments. At each study location, fifteen fragments were collected in three groups of five samples taken at least five metres apart.

For $\mathrm{pH}, \mathrm{EC}$ and SAR determinations, 272 near-surface materials were sampled from 40 spoil pile and 19 restored minesoil sites; materials were taken at $0-0.15 \mathrm{~m}$ so as to include the root zone of potentially establishing plants. Natural local soils (Blackwater, vertisols; Gregory, vertisols; Oaky Creek, vertisols, alfisols; Saraji, vertisols, alfisols) were also sampled $(0-0.15 \mathrm{~m})$ at all mines at low intensity. Two locations were sampled $(n=5)$ at Blackwater and Gregory Mines while at Oaky Creek three samples were taken from each soil; samples were taken from each of two alfisols $(n=5)$ and one vertisol $(n=5)$ at Saraji Mine. 


\subsection{Analytical methods}

Laboratory-based dispersion tests involved immersing the sampled aggregates and crust fragments in deionised water and allocating a score depending on the observed degree of slaking and dispersion after periods of 2 and 20 hours (Loveday \& Pyle 1973). In these tests, scores greater than eight indicated dispersion of the contained clays.

Unless specified otherwise, the $\mathrm{pH}, \mathrm{EC}$ and SAR values reported here for soils, spoils and restored sites were made in aqueous suspensions at a soil: solution ratio of 1:5 (Rayment \& Higginson 1992). Salinity was estimated as EC. The concentrations of $\mathrm{Ca}, \mathrm{Mg}$ and $\mathrm{Na}$ in the 1:5 aqueous suspensions were used to calculate sample SAR values. At this dilution, SAR values greater than three are considered to indicate sodic materials (Department of Environment and Resource Management 2011; Shaw 1999).

The results of statistical comparisons of $\mathrm{pH}, \mathrm{EC}$ and SAR values among minesoils sampled from each mine and between spoils and restored environments are presented below. In most comparisons, the variances for all three measures were very highly significantly different between samples $(P<0.001$, Levene's test). Differences between mines, and between restored minesoils and unmodified spoils within each mine, were therefore tested using Welch's test. Individual sample differences were tested using Games Howell comparisons at a significance level of 0.05 . Computations were carried out using 'Minitab' software, version 17 (Anonymous 2015b).

\section{$4 \quad$ Minesoils and their properties}

In terms of the Australian Soil Classification (Isbell 1996), the natural soils of the total of the 446,726 ha of mine lease areas in the Basin are, in decreasing order of area: vertosols (53\%), sodosols (32\%), kandosols (11\%), chromosols (4\%) and rudosols (1\%) (Erskine \& Fletcher 2013). Expressed in terms of Soil Taxonomy (Soil Survey Staff 2014), approximately equivalent groupings are, respectively: vertisols, alfisols, ultisols, ultisols and entisols; the soil moisture regime is ustic.

The limited amounts of good quality, fully developed natural soil available for use in rehabilitation practice may constrain the success of restoration works. Further, some widespread local natural soils are of poor quality for restoration purposes: the sodosols have, by definition, a sodic B horizon underlying an often thin A horizon and the vertosols and chromosols may be sodic at depth. Losses may occur during initial stripping or through poor management of stored soil resources.

For purposes of this paper, minesoils are considered as incipient soils forming on spoil materials, wastes and their transported erosion products in post-mining landscapes. Primary minesoils are those forming in place from waste rock and related materials and secondary as those forming in valley floors, colluvial footslopes, alluvial and channel sites, in drainage depressions and also in microsites within areas of primary minesoils or restored sites. Composite minesoils are formed of layered materials (semi-impermeable layers, capillary break materials, layers of surface-applied natural soils) placed over spoil materials or wastes. When stable landforms are constructed and given effective biological inputs, they develop some of the characteristics of soils, provided that their chemical and physical properties fall within the range of normal biological processes (see, for example, Tongway and Ludwig 2011).

\subsection{Minesoil development}

In Australia, minesoils are included in a grouping of soils forming in human-influenced or human-modified materials, mostly classified as spolic anthroposols in terms of the Australian Soil Classification (Isbell 1996). They also have similarities to soils forming on other unconsolidated materials such as recent alluvium, loess, glacial till, airfall tephra and lacustrine deposits. In different international soil classification systems, minesoils and other human-influenced soils have been included within technosols (ISSS Working Group WRB 2014) and in the entisols, inceptisols and in other groups within Soil Taxonomy (Bockheim et al. 2014). Currently, no widely accepted system based on pedological inference exists for their classification. 
As with other soils, minesoils develop under the influence of the five soil forming factors: time, climate, parent materials, topography and biological influences (see, for example, Johnson and Hole 1994). Their definition emphasises the dominant effects of humankind (Richter 2007) in determining landform characteristics and the placement of spoil materials and, sometimes, the soils used to help in restoring a vegetation cover. Spain et al. (1995a) considered the soil forming factors in the context of the Bowen Basin post-mining environment.

Only short periods have elapsed in the Bowen Basin postmining environment for soil development to occur (Roe 1992) and at this time most minesoils are less than c. 65 years old. This is a minimal period compared with the ages of the fully-developed soils in the area and implies that a long period of change and redistribution of minesoil materials will occur due to the altered environmental conditions in which the near-surface materials now occur. While thin A horizons have been found in primary minesoils (Sencindiver \& Ammons 2000), Birkeland (1984) considered that the full development of an A horizon is likely to take more than 100 years, while short-cycle soils such as the vertisols widespread in the Bowen Basin may form over time scales of c. 1000 years and the alfisols over 10,000 to 100,000 years.

In the coal mining industry, minesoil parent materials include a diverse range of variably weathered and often partially mixed materials derived from the sedimentary rocks and shales, alluvial and other materials that form the upper part of the stratigraphic column. More specifically, they include the overburden and interburden materials lying above and between the coal seams being mined. They may also include oxidised coals and sub-economic coal seam materials discarded with the overburden. Sandstones and other sedimentary rocks forming the upper part of the stratigraphic column and weathered during the Tertiary period have been considered substantially less stable than their underlying unweathered materials (Kelly \& Kelly 1987).

The sedimentary rocks and other parent materials are partly fractured by explosives and by the handling associated with overburden removal and mining processes and during the landform reshaping and preparation that occurs in the course of rehabilitation. Such treatment greatly increases their specific surface areas leading to rapid physical, and in some places chemical weathering associated with pyrite oxidation through exposure to oxygen and water. The properties of these rapidly-changing materials define the initial conditions for the developing minesoils (Chesworth 1973).

Spatial variation in primary minesoils largely results from the properties of the various materials included in the spoil mixture, notably those placed at and near the surfaces of the landforms created. Within the Bowen Basin, such materials will differ between coal measures and, at the scale of a mine, along its length due to such processes as faulting, displacement and alluviation. Due to the dip of most coal seams, as open-cut mining proceeds across a pit (Figure 1), the increasing overburden depth implies a systematically diminishing proportion of weathered to unweathered materials with increasing distance across the spoil pile sequence. For example, Kelly and Kelly (1987) reported gradients of diminishing $\mathrm{pH}$ and salinity across a spoil pile sequence at Saraji Mine. In addition, as mining proceeds, materials from one or more sub-economic coal seams may start to be included in the spoil piles (Figure 1), potentially influencing spoil characteristics in a major way.

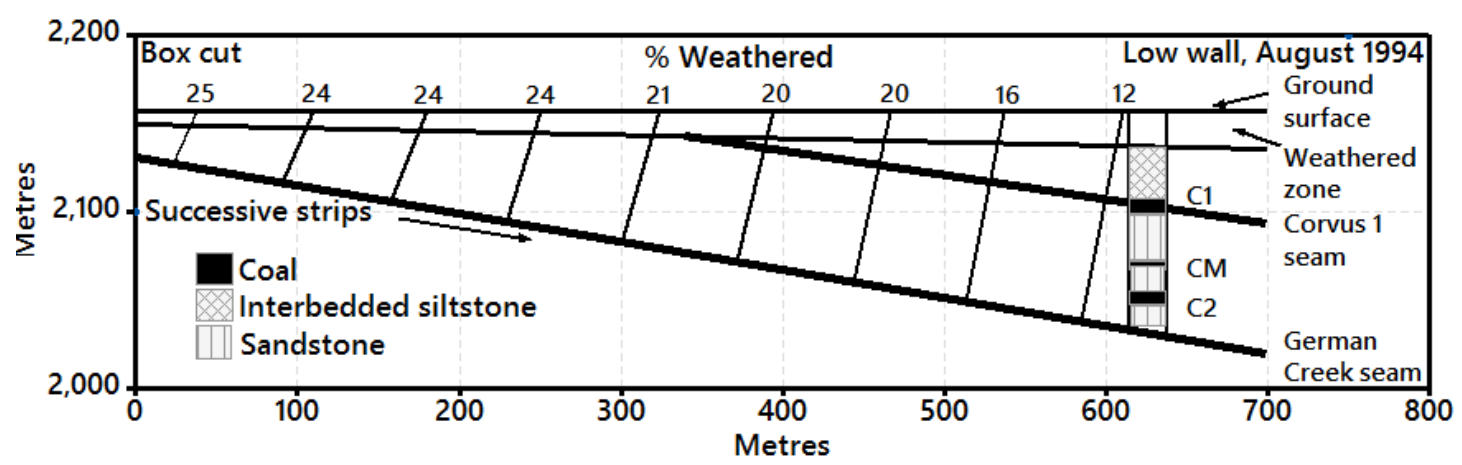

Figure 1 Idealised cross-section of a pit at Oaky Creek Mine showing the declining proportion of the spoil comprised by the weathered materials with progression of mining across the pit and the entry of unmined seams (Corvus seam) into the overburden materials (stratigraphic section simplified from Esterle, in Spain et al. 1997) 


\subsection{Selected physical properties}

The physical properties of the rapidly developing Bowen Basin minesoils remains poorly known, as well as how representative the limited number of values, so far measured, are of the entire Basin.

\subsubsection{Field textures}

The parent materials of the Bowen Basin minesoils range from variably-weathered mudstones to sandstones to shales and, therefore, give rise to minesoils of diverse textures. As noted elsewhere (see, for example, Down 1975), near-surface texture differs widely due to the different parent materials present and the segregation associated with materials handling. Texture may change rapidly following spoil deposition as a consequence of accelerated erosion and subsequent transport, and due to the active physical (and sometimes chemical) weathering, which may also lead to the release of contained clays (Baker et al. 1993).

Field textures were determined on 355 minesoil materials (208 from restored environments and 147 from spoil pile sites), sampled largely from the upper one metre of the 98 minesoil profiles studied at the four mines. Figure 2 presents the frequency distributions of minesoil field textures from the four mines. Over all four mines, the modal class was clay loams ( $28 \%$ of the records) followed by sandy loams (18\%) and light clays (15\%). Differences in modal class occurred between the mines: clay loams were the highest modal class at Blackwater, Gregory and Saraji Mines, but at Oaky Creek Mine, sandy loams were most common (38\%) and few clay field textures were recorded. Sands comprised $10 \%$ of all records and were most commonly represented at Saraji (19\%) and at Gregory Mines (17\%). Six of the local soils were vertisols, which comprised fine-textured materials throughout the profile, but sometimes had a lighter-textured near-surface layer; one was an alfisol, with a light-textured $A$ horizon overlying a fine-textured $B$ horizon.

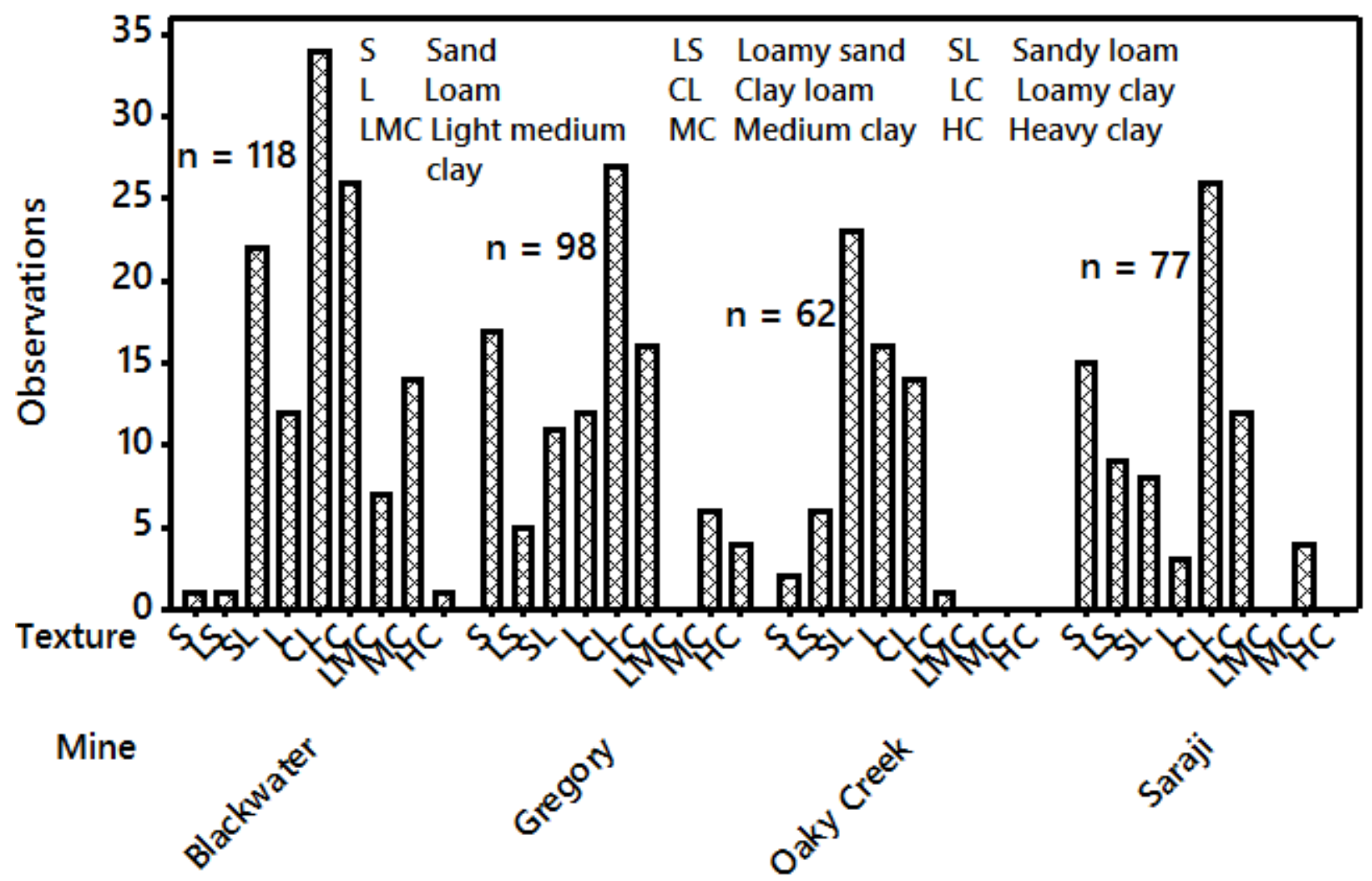

Figure 2 Frequency distributions of minesoil field textures at the four mines $(n=355)$

As with other incipient soils, many minesoils are highly erodible and this has led to the accumulation of materials of different modal texture classes in lower landscape locations. Coarser-textured parent materials accumulate in colluvial footslopes and upper alluvial positions while finer materials are transported further 
downslope to accumulate in the lower parts of depressions. Figure 3 illustrates the particle size distributions of fine earth materials sampled from a 13-year-old spoil pile system at Blackwater Mine. Pore blockage by fine materials may lead to waterlogging or the formation of temporary to seasonal wetlands perched above the water table of the local unmined landscape. Expansive clays derived from the minerals present in overburdens lead to shrink-swell behaviour on drying and wetting in the primary minesoils and in the finer textured materials found in lower landscape positions.

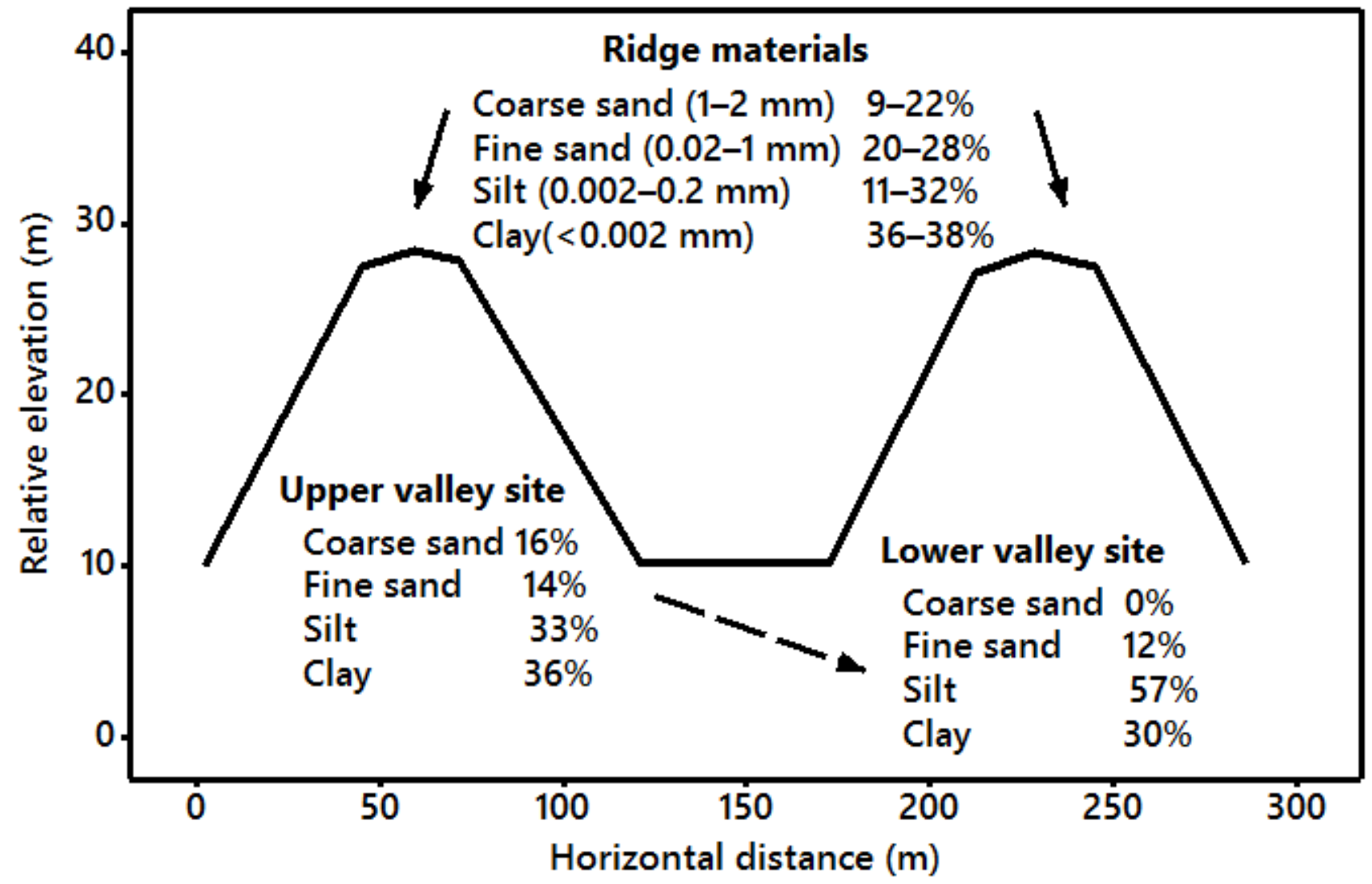

Figure 3 Particle size distributions of minesoils at different landscape positions in a spoil pile environment at Blackwater Mine (Spain et al. 1995a)

Primary minesoils are often very stony (Sencindiver \& Ammons 2000). However, due to the rapid physical weathering that occurs following deposition, many of the larger particles ( $>2 \mathrm{~mm}$ ) may be fragile and therefore difficult to assess accurately. In contrast to fully-developed soils, the proportions of many minesoil materials passing the larger sieve sizes may depend on the energy applied to the sieving.

\subsubsection{Structure}

Reflecting their incipiency, minesoils generally have low wet strengths and weak structural development and may remain in this state for long periods. For example, in the United Kingdom, Down (1975) reported continuing instability in colliery spoils, even after 178 years of soil development.

Instability is also apparent in many Bowen Basin minesoils studied so far. Results from simple immersion tests (Loveday \& Pyle 1973) have indicated that most surface-sampled minesoil aggregates and crust fragments were unstable in deionised water. Of minesoil aggregate and surface crust materials sampled from 59 sites at the four mines, $53(90 \%)$ dispersed in deionised water. Only small differences were found between restored and spoil pile environments: median values at all 36 spoil-pile sites exceeded eight while 17 of 20 sites sampled in restored environments also had median values greater than eight. Of three sites that had been topdressed with a natural soil, two had median scores that indicated relative stability. 
These findings are illustrated by data from Oaky Creek Mine (Figure 4), where almost all minesoil materials dispersed in water. That is, with the exception of two samples taken from rehabilitated environments, where the spoils had been topdressed with a natural soil. The surface materials of one natural soil (a vertisol) were also dispersive while those of an alfisol were essentially stable.

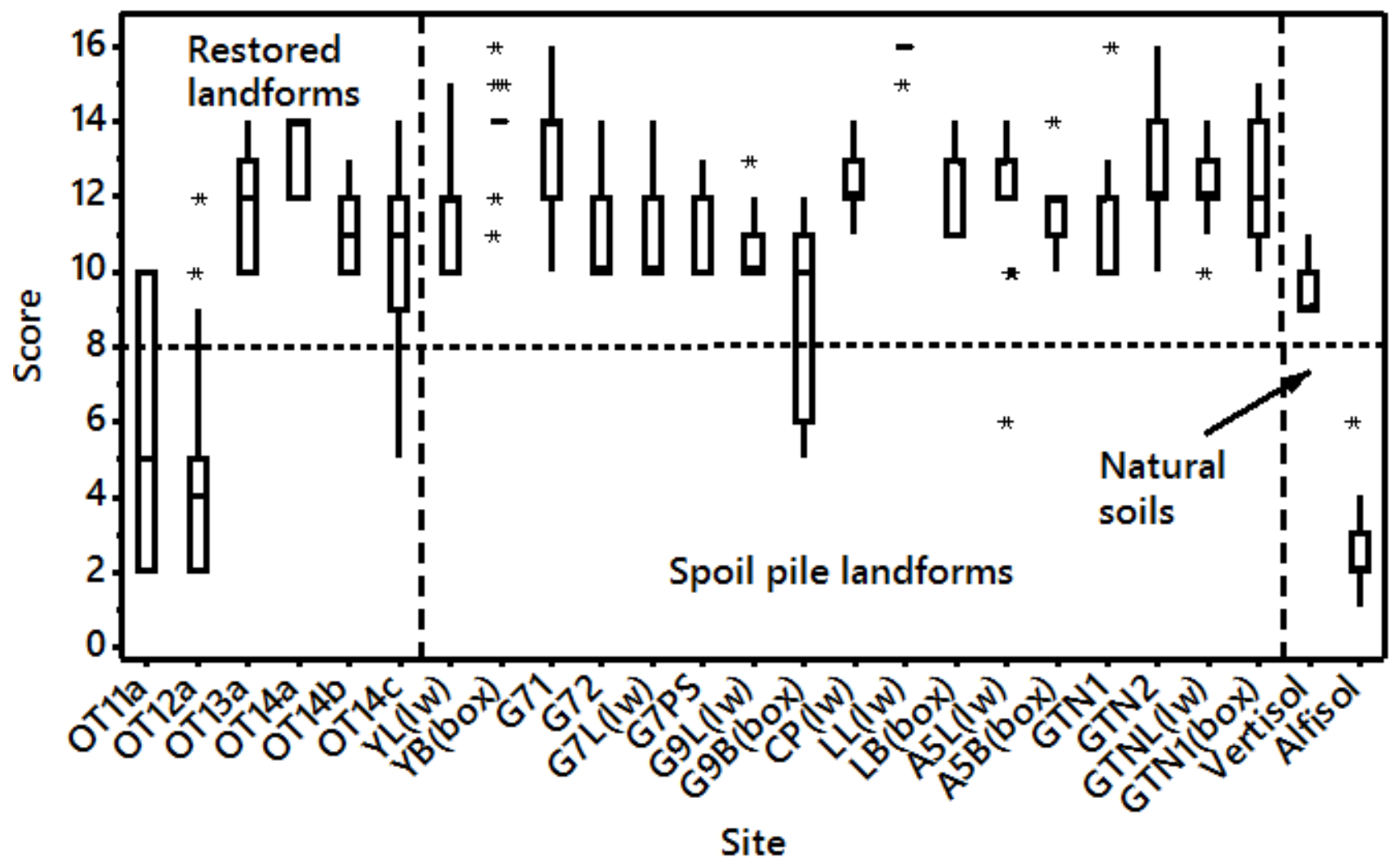

Figure 4 Dispersion test scores (medians and interquartile ranges) of surface-sampled aggregates and crust fragments in de-ionised water in 23 minesoils and two natural soils from Oaky Creek Mine ( $n=15$ at each site); minesoils at sites OT11a and OT12a had a surface layer of applied soil (scores $>8$ imply dispersion, the * indicates outlying values)

A particular feature of minesoil structure is the frequent development of substantial surface crusts. Table 2 illustrates the thickness of structural crusts measured at different positions in a 13-year-old spoil pile landscape at the northern end of Blackwater Mine (Whiting 1995). Chemical crusting and salt efflorescences are also apparent in some mines, notably those of the German Creek Formation, in which minesoils tend to contain higher concentrations of reactive sulphides. At Gregory and Oaky Creek Mines, exposed sulphidic spoil materials derived from the German Creek pits (German Creek Seam to Corvus Seam interval) oxidise rapidly to produce heat, efflorescences and 'puffs', the single-grain products of acid sulphate weathering.

In comparison with fully-developed soils, biologically-derived structure in Bowen Basin minesoils is minimal. This type of structure is that directly associated with plant roots and with constructs created by ants and termites. It is most clearly expressed in the sandy materials characteristic of colluvial footslope locations. 
Table 2 Mean thicknesses and standard deviations of crusts present at different locations on sodic materials exposed for 13 years at Blackwater Mine (Whiting 1995)

\begin{tabular}{ccccc}
\hline Parent material & Landscape position & $\begin{array}{c}\text { Mean crust } \\
\text { thickness }(\mathbf{m m})\end{array}$ & $\begin{array}{c}\text { Standard } \\
\text { deviation }\end{array}$ & Sample size \\
\hline Tertiary & crest & 30 & 10 & 50 \\
\hline Tertiary & midslope & 35 & 10 & 50 \\
\hline Mixed & colluvial footslope & 2 & 1 & 36 \\
\hline Mixed & immit & 1 & 0.3 & 50 \\
\hline Permian & crest & 38 & 12 & 50 \\
\hline Permian & midslope & 37 & 12 & 50 \\
\hline
\end{tabular}

\subsection{Chemical properties}

The chemical properties of Bowen Basin minesoils differ broadly at a range of scales, depending on the materials placed in the near-surface layers of the spoil piles and recreated landforms. Widely ranging $\mathrm{pH}$ values occur in many minesoil environments, and extremes may lead to plant nutrient limitations and to toxicities. As a 'master' variable, soil pH controls the availability of a range of elements taken up by plants and micro-organisms (Rengel 2002) and is the most commonly used indicator of spoil quality (Sheoran et al. 2010). High salinities and sodicity limit plant growth (Marcar \& Crawford 2004) and influence the activities of microorganisms (see, for example, Wong et al. 2008) and therefore C relationships (Wong et al. 2010).

\subsection{1 pH, salinity and sodicity}

Figures 5 (a), (b) and (c) present, respectively, the $\mathrm{pH}$, salinity (expressed as EC) and the SAR values for 272 minesoils $(0-0.15 \mathrm{~m})$ sampled from 59 spoil pile and restored environments at Blackwater, Gregory, Oaky Creek and Saraji Mines. Table 3 presents the results of analyses of the differences in $\mathrm{pH}$, salinity and sodicity between minesoils at the three mines. 


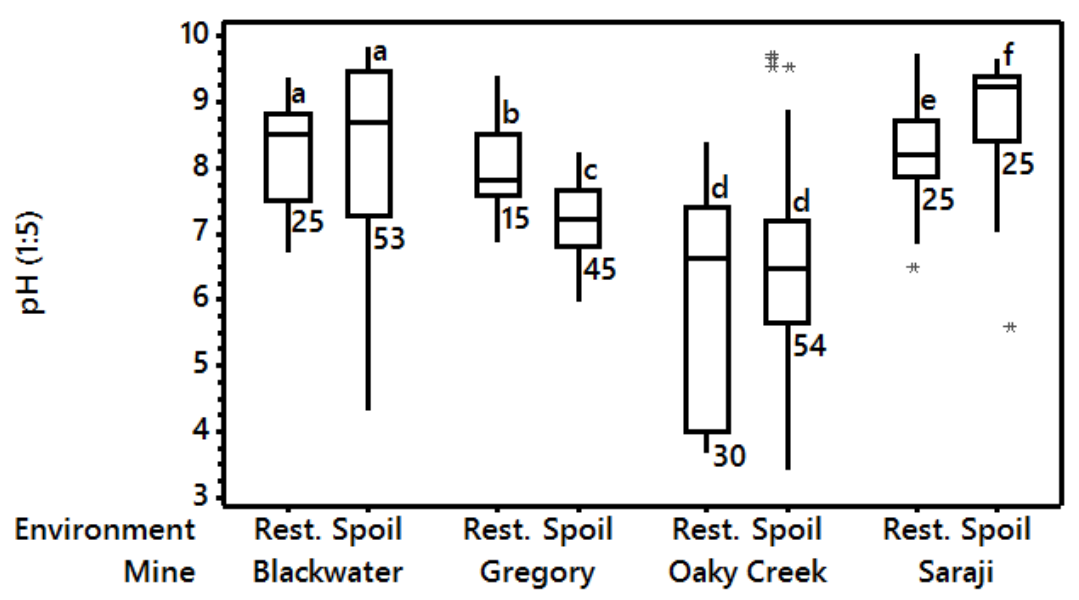

(a) $\mathrm{pH}$

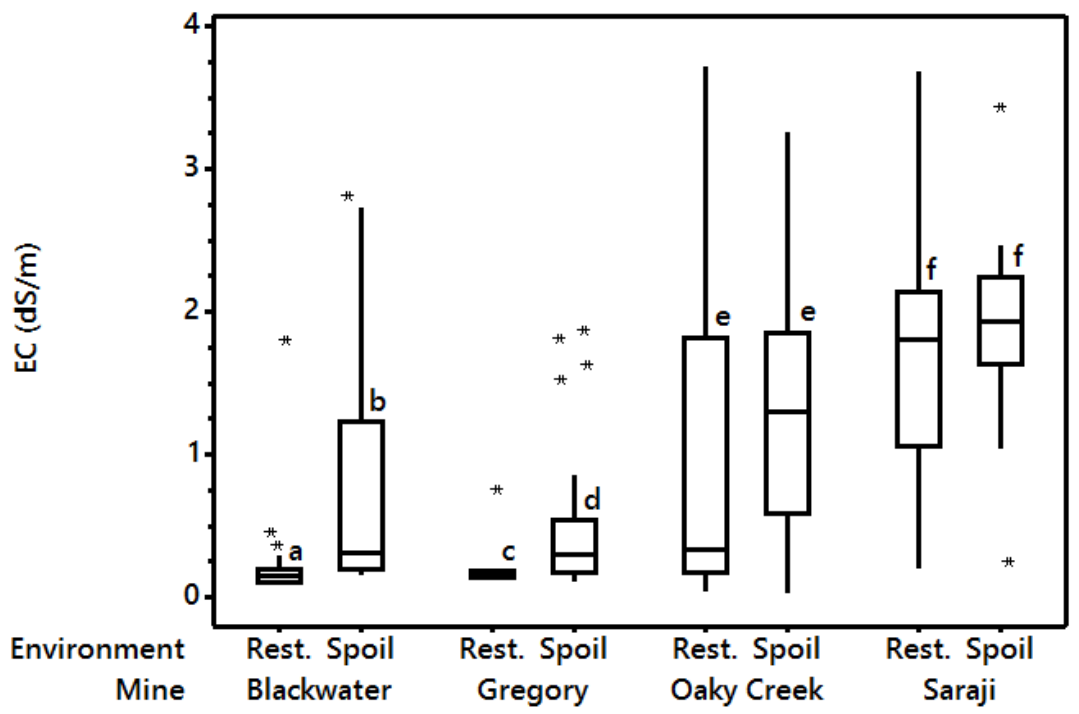

(b) EC

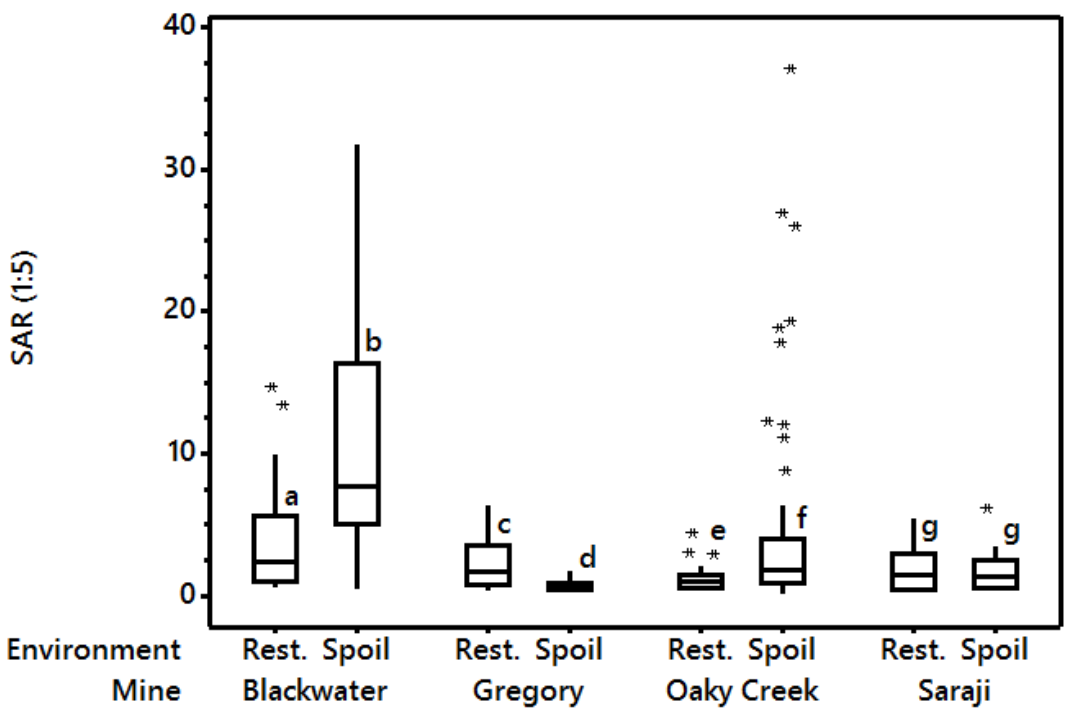

(c) SAR

Figure 5 Box plots of (a) $\mathrm{pH}$, (b) EC and (c) SAR values for 272 near-surface (0-0.15 m) samples from spoils and restored sites in four Bowen Basin mines; sample size is indicated for $\mathrm{pH}$ only and, within mines, a similar lower case letter indicates a non-significant difference $(a t P<0.05)$ between spoils and restored sites 
Table 3 Comparisons of minesoil pH, EC and SAR between mines made using Welch's test and Games Howell comparisons between individual mines; a similar lower case superscript indicates no significant differences between mines at $\mathrm{P}<0.05$

\begin{tabular}{|c|c|c|c|c|c|c|c|}
\hline & $\mathbf{F}$ & $\mathbf{P}$ & df & \multicolumn{4}{|c|}{ Mine } \\
\hline $\mathrm{pH}$ & 39.31 & $<0.001$ & $3,143.061$ & aBlackwater & ${ }^{\mathrm{b}}$ Gregory & 'Oaky Creek & aSaraji \\
\hline $\mathrm{EC}$ & 57.34 & $<0.001$ & $3,137.592$ & 'Blackwater & ${ }^{c}$ Gregory & ${ }^{b}$ Oaky Creek & aSaraji \\
\hline SAR & 26.95 & $<0.001$ & $3,143.333$ & aBlackwater & ${ }^{\mathrm{C}}$ Gregory & ${ }^{b}$ Oaky Creek & ${ }^{b c}$ Saraji \\
\hline
\end{tabular}

The $\mathrm{pH}$ values (water, 1:5) of the near-surface minesoil materials ranged from extremely acid in some sulphuric materials (c. 2.7 in some acid seeps) to very strongly alkaline (>10), although most were less extreme. Median pH over the 272 samples was 7.57 (interquartile range 6.69 to 8.69): the frequency distribution was polymodal with a minor mode at 4.0, the major mode at 7.25 and two further minor modes at 8.7 and 9.5. Across all mines, there was no consistent pattern of differences between the restored minesoils and the spoils within each mine: both materials had similar values at Blackwater and Oaky Creek, but at Gregory Mine values for restored environments were greater than those for unrestored soils, while at Saraji Mine, the opposite situation pertained (Figure 5a). Over all minesoil materials analysed, Blackwater and Saraji had the highest pH values and these were, in decreasing order, greater than those at Gregory and Oaky Creek Mines.

Sampling intensity in the local natural soils (vertisols and alfisols) was considered too low for statistical analysis. Sample $\mathrm{pH}$ values in the 41 near-surface $(0-0.15 \mathrm{~m})$ natural soils (vertisols, alfisols) sampled at all sites ranged from 5.71 to 7.58. Values were lowest in the natural soils at Blackwater and Saraji Mines but fell within the ranges of minesoil values recorded at Gregory and Oaky Creek Mines.

Sampled minesoil EC values ranged from 0.06 to $4.85 \mathrm{dS} / \mathrm{m}$ over the four mines, with a median value of $0.50 \mathrm{dS} / \mathrm{m}$ (interquartile range 0.18 to $1.67 \mathrm{dS} / \mathrm{m}$ ). The frequency distribution was bimodal with a major mode at $0.20 \mathrm{dS} / \mathrm{m}$ and a minor mode at $1.80 \mathrm{dS} / \mathrm{m}$. Over all minesoils, EC was very highly significantly correlated with the concentrations of $\mathrm{Ca}, \mathrm{Mg}, \mathrm{Na}, \mathrm{S}$, and $\mathrm{Cl}$ (all $\mathrm{P}<0.001)$, but not with $\mathrm{K}(\mathrm{P}>0.05)$.

Over all four mines, minesoil EC values were lower in the restored than in the spoil pile environments, although these differences were not significant at Oaky Creek and Saraji Mines. Over both material classes, the minesoils at Saraji were the most saline and were significantly more so than at Oaky Creek; materials from Oaky Creek Mine were more saline than those from Blackwater and Gregory mines, which did not differ in salinity (Figure $5 \mathrm{~b}$ ). It should be noted that substantially higher salinities (to $>25 \mathrm{dS} / \mathrm{m}$ ) have been reported from these and other Bowen Basin mines (Li et al. 2014).

The EC values of the 41 near-surface $(0-0.15 \mathrm{~m})$ natural soils (vertisols, alfisols) sampled at all sites ranged from $0.10-4.23 \mathrm{dS} / \mathrm{m}$. Such values were lower in the natural soils than in the minesoils at all mines except Saraji, where they were similar.

The texture of the growing medium has a major influence on the expression of salt tolerance in plants (Marcar \& Crawford 2004). Assuming a clay loam field texture and using a multiplier of nine (Marcar \& Crawford 2004) to convert the median value of $0.50 \mathrm{dS} / \mathrm{m}$ to its approximately equivalent value in a saturation extract, the value would be c. $4.5 \mathrm{dS} / \mathrm{m}$. To grow adequately in materials of this EC, plants would need to be at least moderately salt-tolerant. In a minesoil of sandy texture and an EC (1:5) of $0.50 \mathrm{dS} / \mathrm{m}$, an approximately equivalent value in a saturation extract would be c. $8.5 \mathrm{dS} / \mathrm{m}$; to grow adequately in such materials, plants would need to be extremely salt tolerant (Marcar \& Crawford 2004).

Figure 6 plots EC against pH for 272 minesoils sampled from the four mines (Spain et al. 1995b, 1997). Based on a clay loam texture, this plot also indicates the generalised tolerance limits of different groups of higher plants based on $\mathrm{EC}$ and $\mathrm{pH}$, ignoring possible interactions. Plant $\mathrm{pH}$ tolerances vary widely, and some species have clear adaptations to a particular $\mathrm{pH}$ range, but as $\mathrm{pH}$ falls below the approximate range of 5-7.8, they are likely to suffer increasing stress because of the higher solubilities of acidic cations ( $\mathrm{Al}, \mathrm{Mn})$ and the 
reduced availability of $\mathrm{N}, \mathrm{P}$ and other nutrient elements. Solubilities of $\mathrm{Al}$ and $\mathrm{Mn}$ increase again above approximate $\mathrm{pH}$ values of 7.8 .

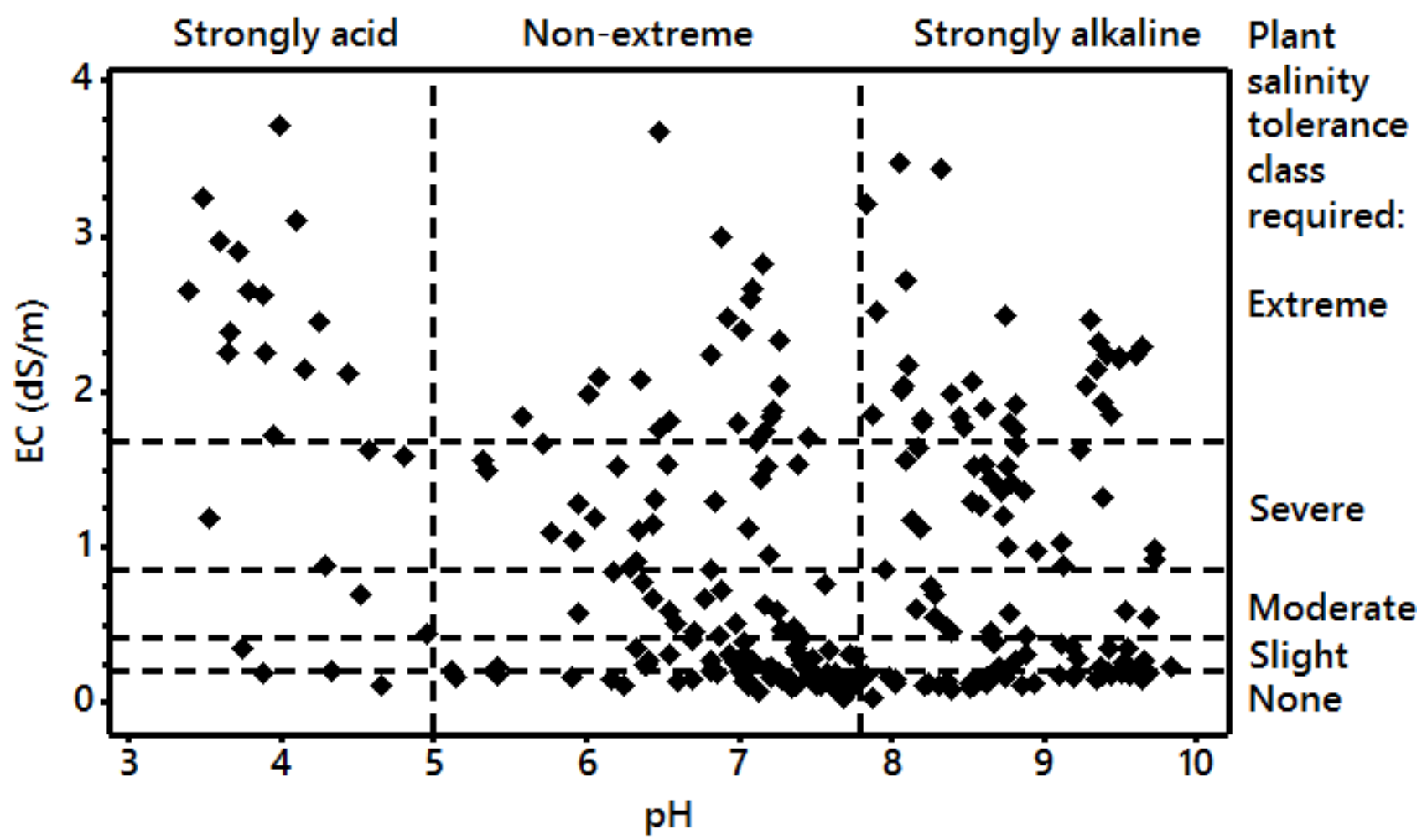

Figure $6 \mathrm{pH}$ and EC (both water, 1:5) in 272 minesoils from four Bowen Basin mines; the horizontal lines indicate the approximate upper limits of salt tolerance required for adequate growth of four classes of plants, assuming a clay loam field texture (Marcar \& Crawford 2004)

The 1:5 aqueous solution concentrations of $\mathrm{Ca}, \mathrm{Mg}$ and $\mathrm{Na}$ were used to calculate the SAR values of the minesoils from the four mines (Figure $5 \mathrm{c}$ ). At this dilution, SAR values greater than three are considered to indicate sodic materials (Hazleton \& Murphy 2007; Rengasamy \& Olsson 1991). Over all 272 minesoil samples, the SAR values ranged from $<1$ to 37 , with a median value of 2 (interquartile range 1 to 37). The frequency distribution had a single modal class of $0-1$ and was strongly right skewed: $33 \%$ of the samples were sodic $(S A R>3)$.

Very highly significant differences occurred between the mines: the Blackwater minesoils were substantially more sodic than those of the other mines, with lowest median values apparent at Oaky Creek and Gregory Mines (Table 3). Values of SAR in the spoil pile environment at Oaky Creek Mine were particularly variable. Spoil SAR values differed significantly from those of the restored sites at all mines except Saraji, although these differences were inconsistent in direction between the three remaining mines (Figure 5 (c)).

Values of the SAR in the 41 near-surface $(0-0.15 \mathrm{~m})$ natural soils (vertisols, alfisols) sampled at all sites ranged from $<1$ to 3. Values were lower in the natural soils than in the minesoils at Blackwater and Saraji Mines but fell within the range of minesoil values at the remaining two mines. Sodic materials are considered inimical to plant growth, both for their direct effects on root tissues and through their effects on the growing medium.

\subsubsection{Minesoil classification based on $\mathrm{pH}$ and salt status}

Table 4 divides the 272 minesoil records into 12 classes based on three $\mathrm{pH}$ ranges (acid: <5; non-extreme 5-7.8; alkaline: >7.8) and four groupings reflecting salt status, the latter based on salinity and sodicity. Materials were classified as saline if their EC (1:5) values exceeded $0.84 \mathrm{dS} / \mathrm{m}$ ('moderately' saline, Marcar \& Crawford 2004), and sodic if their SAR values exceeded three (Hazleton \& Murphy 2007; Rengasamy \& Olsson 1991). 
Table 4 Minesoils from four Bowen Basin Mines classified (\% records) into 12 classes by pH, salinity and sodicity; materials are considered saline where EC $(1: 5)>0.84 \mathrm{dS} / \mathrm{m}$ and sodic where SAR $(1: 5)$ $>3(n=272)$

\begin{tabular}{ccccc}
\hline Salt status & \multicolumn{4}{c}{ pH status } \\
& $<5.0$ & $\mathbf{5 . 0 - 7 . 8}$ & $>\mathbf{7 . 8}$ & All \\
\hline Saline, non-sodic & 6.2 & 11.0 & 14.0 & 31.2 \\
\hline Saline-sodic & 0.7 & 4.8 & 6.2 & 11.7 \\
Sodic, non-saline & 0.7 & 3.3 & 16.9 & 20.9 \\
\hline Non-extreme & 1.5 & 27.2 & 7.4 & 36.1 \\
\hline All & 9.1 & 46.3 & 44.5 & \\
\hline
\end{tabular}

Considering the three measures individually, approximately $46 \%$ of records lie within the non-extreme $\mathrm{pH}$ range, $43 \%$ are at least moderately saline and $33 \%$ are sodic. It should be noted that about $27 \%$ of the materials sampled were 'non-extreme' on the combined three measures.

Elevated salinity potentially limits soil development (Brewer 1954) and plant growth (Munns \& Tester 2008) and modifies soil microbial activity (Wong et al. 2008); it thereby constrains other aspects of ecosystem development. Assuming a clay loam texture to convert 1:5 solution values to their equivalent saturation extract estimates, the approximate upper EC tolerances of four classes of plants are indicated in Figure 4 (Marcar \& Crawford 2004). It should be noted that only 59\% of the samples fell within the EC region where plants of slight to moderate salt tolerance are likely to succeed; c. $24 \%$ of the samples were sufficiently saline to make it unlikely that even the most salt tolerant higher plants would survive in these materials. Sodic materials can be inimical to plant growth on both physical and chemical grounds (Marschner 1995; Rengasamy 2010) and consequently feature in stockpile management for mine rehabilitation works (Department of Minerals and Energy 1995; Shaw 1999).

\section{Conclusion}

The minesoils developing in Bowen Basin post-mining landscapes are a diverse group of incipient soils forming in the geomorphologically immature landscapes of the recent post-mining environment. Consistent with their often poor coherence and chemical properties that may lead to dispersion of contained clays, most primary minesoils are likely to continue undergoing high erosion rates (although these will be moderated by vegetation development, see, for example, Carroll et al. (2004). Consequently, both spoil-pile and restored landscapes are expected to continue differentiating rapidly for some time with ongoing development of coarse-textured colluvial footslope and alluvial deposits, and with finer-textured clay-rich and silt-rich deposits accumulating in the lowest parts of the landscapes (see also Tongway and Ludwig 2011).

The combined effects of the above processes will act to limit soil formation rates in both the eroding materials and those in lower landscape positions, which will continue to have materials from upslope deposited on their surfaces. As with incipient soils elsewhere (Chesworth 1973), minesoils forming in place have differentiated little from their parent materials, with minimal profile development apparent below the surface $(50 \mathrm{~mm})$. However, this clearly differs for profiles forming in transported materials.

Clay loam was the most common field texture at three mines and sandy loam at the fourth. Texture additionally differs with landscape position and larger-scale variation may occur between mines located in different parts of the Basin. Substantial structural surface crusts develop in these (and other) minesoils, with the formation of salt crusts in some materials, especially in lower landscape locations. Biologically formed structure is largely confined to that directly associated with roots and to faunal constructs.

Minesoils exhibited a much wider range of $\mathrm{pH}$ values than local natural soils, with approximately half of minesoil $\mathrm{pH}$ values outside the optimal range for unspecialised plant species. This indicates increasingly 
higher nutritional and possibly toxicity stresses in plants growing on these media the further they depart from the above range. Similarly, minesoil materials ranged in salinity from low to extremely high values, some probably exceeding the tolerance of even extremely halophytic plants (Marcar \& Crawford 2004). Approximately one third of materials were sodic, which reinforces the results of dispersion testing and confirms their unstable character.

It has been usual to consider separately the individual effects of the above measures of minesoil quality on plant success although recent work on Australian acacias (Bui et al. 2014) indicates interaction between pH and salinity, and it is likely that tripartite interactions that include sodicity will also be demonstrated. Nonetheless, classification of minesoil materials based jointly on the three measures provides indices of potential nutrient availability to plants and potential stresses from salinity and sodicity, as well as substrate stability. As it does in the management of natural soils (Rengasamy 2010), such classification can contribute to management by indicating the stress tolerance required in plants to be used in particular minesoil environments and the probability of successful plant community and soil development processes.

Long-term endpoints for minesoil development are currently unclear but will depend strongly on landform design. Improved knowledge of minesoil development will hopefully lead to better minesoil management so that postmining landscapes may eventually stabilise and their ecosystems can offer a similar range of goods and services as their counterparts on natural soils.

\section{Acknowledgement}

We thank the then BHP Alliance Coal Operations Pty Ltd and Xstrata Queensland Ltd for permission to include data from unpublished reports to these companies.

\section{References}

Anonymous 2015a, Queensland's coal - mines and advanced projects, Department of Natural Resources and Mines, Queensland, viewed 12 September 2015, https://www.dnrm.qld.gov.au/_data/assets/pdf_file/0011/238079/coal.pdf

Anonymous 2015b, Minitab version 17, viewed 28 August 2015, http://www.minitab.com/en-us/

Baker, JC, Fielding, CR, de Caritat, P \& Wilkinson, MM 1993, 'Permian evolution of sandstone composition in a complex back-arc extensional to foreland basin: the Bowen Basin', Journal of Sedimentary Petrology, vol. 63, pp. 881-893.

Birkeland, P 1984, Soils and Geomorphology, Oxford University Press: N.Y.

Bockheim, JG, Gennadiyev, AN, Hartemink, AE \& Brevik, EC 2014, 'Soil-forming factors and Soil Taxonomy', Geoderma, vol. 226-227, pp. 231-237.

Brewer, R 1954, 'Soil parent material', The Australian Journal of Science, pp. 134-138.

Bui, EN, Thornhill, A \& Miller, JT 2014, 'Salt- and alkaline-tolerance are linked in Acacia', Biology Letters, vol. 10, DOI: $10.1098 /$ rsbl.2014.0278.

Carroll, C, Pink, L \& Burger, P 2004, 'Coalmine rehabilitation: a long term erosion and water quality study on Central Queensland coalmines', in ISCO 2004, 13th International Soil Conservation Organisation Conference, Conserving Soil and Water for Society: Sharing Solutions, paper 406, p. 6.

Chesworth, W 1973, 'The parent rock effect in the genesis of soil', Geoderma, vol. 10, pp. 215-225.

Department of Environment and Resource Management 2011, Salinity Management Handbook, Second edition, Department of Environment and Resource Management, Queensland.

Department of Minerals and Energy 1995, Technical Guidelines for the Environmental Management of Exploration and Mining in Queensland: Part B Assessment and Management of Saline/Sodic Wastes, Queensland Government, Brisbane.

Down, $\mathrm{CH}$ 1975, 'Soil development on colliery waste tips in relation to age. 1. Introduction and physical factors', Journal of Applied Ecology, vol. 12, pp. 613-622.

Erskine, PD \& Fletcher, AT 2013, 'Novel ecosystems created by coal mines in central Queensland's Bowen Basin', Ecological Processes, vol. 2, 33, p. 12.

Hazleton, P \& Murphy, B 2007, Interpreting Test Results, CSIRO Publishing, Collingwood.

Hutton, AC 2009, 'Geological setting of Australian coal deposits', in R Kininmonth \& E Baafi (eds), Australasian Coal Mining Practice, The Australasian Institute of Mining and Metallurgy, Carlton, Victoria.

Isbell, RF 1996, The Australian Soil Classification System, CSIRO Publishing, Melbourne.

ISSS Working Group WRB 2014, 'World Reference Base for Soil Resources 2014, International Soil Classification System for Naming Soils and Creating Legends for Soil Maps', World Soil Resources Reports No. 106, FAO, Rome.

Johnson, DL \& Hole, FD 1994, 'Soil formation theory: a summary of its principal impacts on geography, geomorphology, soil-geomorphology, Quaternary geology and palaeopedology', in R Amundson, J Harden \& M Singer (eds), Factors of Soil Formation: A Fiftieth Anniversary Retrospective, Soil Science Society of America, Madison, Wisconsin. 
Kelly, RE \& Kelly, RE 1987, 'Prediction of some minespoil characteristics from exploration drill hole logs', in Environmental Workshop 1987 Papers, Australian Mining Industry Council, Dickson, ACT, pp. 49-65.

Li, X, Park, JH, Edraki, M \& Baumgartl, T 2014, 'Understanding the salinity issue of coal mine spoils in the context of salt cycle', Environmental Geochemistry and Health, vol. 36, pp. 453-465.

Loveday, J \& Pyle, J 1973, 'The Emerson dispersion test and its relation to hydraulic conductivity', CSIRO Australia, Division of Soils Technical Paper, No. 15, p. 7.

Marcar, N \& Crawford, DF 2004, Trees for Saline Landscapes, Publication 03/108, Rural Industry Research Fund, Kingston, ACT.

Marschner, H 1995, Mineral Nutrition of Higher Plants, Academic Press, London.

Munns, R \& Tester, M 2008, 'Mechanisms of salinity tolerance', Annual Review of Plant Biology, vol. 59, pp. 651-681.

Mutton, AJ 2003, Queensland Coals, Physical and Chemical Properties, Colliery and Company Information, 14th Edition, Department of Natural Resources and Mines, Queensland, Brisbane.

Phillips, JD 2009, 'Soils as extended composite phenotypes', Geoderma, vol. 149, pp. 143-151.

Rayment, GE \& Higginson, FR 1992, Australian Laboratory Handbook of Soil and Water Chemical Methods, Inkata Press, Melbourne. Rengasamy, P 2010, 'Soil processes affecting crop production in salt-affected soil', Functional Plant Biology, vol. 37, pp. 613-620.

Rengasamy, P \& Olsson, KA 1991, 'Sodicity and soil structure', Australian Journal of Soil Research, vol. 29, pp. 935-952.

Rengel, Z 2002, 'Role of pH in availability of ions in soil' in Z. Rengel (ed.), Handbook of Plant Growth, $p H$ as the Master Variable, Marcel Dekker, NY.

Richter, DD 2007, 'Humanity's transformation of earth's soil: pedology's new frontier', Soil Science, vol. 172, pp. $957-967$.

Roe, PA 1992, 'Overview of environmental practices in the Queensland coal mining industry - rehabilitation', in Seventeenth Annual Environmental Workshop 1992 Papers, Australian Mining Industry Council, Dickson, ACT, pp. 49-65.

Roe, PA, Mulligan, DR \& Bell, LC 1996, 'Environmental management of coal mines in the Bowen Basin', in DW Mulligan (ed.), Environmental Management in the Australian Minerals and Energy Industries, UNSW Press/Australian Minerals \& Energy Environment Foundation, Sydney.

Sencindiver, JC \& Ammons, JT 2000, 'Minesoil Genesis and Classification', RI Barnhisel, WL Daniels \& RG Darmondy (eds), Reclamation of Drastically Disturbed Lands, Agronomy Monograph, Monograph No. 41. ASA, Madison WI, pp. 595-613.

Shaw, R 1999, 'Soil salinity-electrical conductivity and chloride', in K Peverill, L Sparrow \& D Reuter (eds), Soil Analysis an Interpretation Manual, CSIRO, Melbourne, pp. 129-146.

Sheoran, V, Sheoran, AS \& Poonia, P 2010, 'Soil reclamation of abandoned mine land by revegetation: a review', International Journal of Soil, Sediment and Water, vol. 3, article 13.

Soil Survey Staff 2014, Keys to Soil Taxonomy, 12th edition, United States Department of Agriculture, Washington DC.

Spain, AV, Esterle, J \& McLennan, TPT 1995a, 'Information from geology: implications for soil formation and rehabilitation in the post coalmining environment, Bowen Basin, Australia', in IL Follington, JW Beeston \& LH Hamilton (eds) Bowen Basin Symposium - 1995: 150 Years On, GSA Inc, Coal Geology Group, Brisbane, pp. 147-155.

Spain, AV, Fitzpatrick, R, Hindley, N, Hollingsworth, I, Jones, Joyce, S, Ludwig, J, McFadzean, S, Playfair, L, Soole, P \& Tongway, D 1995b, 'Measurement of the Rate of Soil Formation in Spoil and Rehabilitated Spoil Landforms at BHP Australia Coal Pty Ltd Mines, Central Queensland', AV Spain (ed), unpublished draft report to BHP Australia Coal, CSIRO Australia, Minesite Rehabilitation Research Program.

Spain, AV, Esterle, J, Hollingsworth, I, Joyce, S, McFadzean, S \& Soole, KP 1997, 'Spoil Characterisation Studies and Minesoil Development at Oaky Creek Coal Mine', unpublished report to Oaky Creek Coal Co, Minesite Rehabilitation Research Program, CSIRO.

Tongway, DJ \& Ludwig, JA 2011, Restoring Disturbed Landscapes, Putting Principles into Practice, Island Press, Washington DC.

Whiting, D 1995, 'Types and Properties of Surface Crust Phenomena Forming on Incipient Soils on Spoil at the Blackwater Mine, Central Queensland', unpublished B.Appl.Sc. (Hons) thesis, Department of Environmental Sciences and Geography, James Cook University of North Queensland.

Wong, VNL, Dalal, RC \& Greene, RSB 2008, 'Salinity and sodicity effects on respiration and microbial biomass of soil', Biology and Fertility of Soils, vol. 44, pp. 943-953.

Wong, VNL, Greene, RSB, Dalal, RC \& Murphy, BW 2010, 'Soil carbon dynamics in saline and sodic soils: a review', Soil Use and Management, vol. 26, pp. 2-11. 